\title{
RES LOGICA MAGISTER. TESTING WITH TEACHERS A GAMIFICA- TION-BASED TABLET APP FOR LANGUAGE LEARNING
}

\author{
Letizia Bollini1 \\ ${ }^{1}$ Department of Psychology, University of Milano-Bicocca (ITALY)
}

\begin{abstract}
The school system is progressively adopting digital technologies as a support for teaching and learning activities. On one hand, new generations of Millenials, digital natives, Gen Z, and iGen are growing with a pervasive and transparent relationship with interactive devices and platforms.

On the other, teachers are facing this revolution with a digital migrant background. Touch, streaming, multitasking, messaging, chatting, real-time feedback, free access, peer relations and social interactions worldwide are the basis of a technology-mediated relationship with the world, with tools and between people natural and spontaneous for students.

Teachers, on the opposite, are more connected with a world of in-presence and monotasking learning activities, with printed books, frontal lessons and periodical tests to verify if notions and concepts have been learned and understood.

The "Res Logica" app for tablet - presented at the ICERI 2015 conference - is aimed to teach (Italian) grammar to students age 11-14 years. It proposes a way to use digital technologies, based both on a gamification approach and on the dynamics of social interaction among peers typical of social networks and web 2.0 era. In the first phase of the research project (2012-15) it has been prototyped end tested with students to evaluate and assess the original hypothesis,

The second research phase (2016-17) a spin-off has been developed. This aside app is explicitly addressed to teachers has been designed, prototyped and tested to understand how they react to digital innovation and mobile technologies as teaching support.

Res-Logica Magister - the tablet app targeted on theaters - implements some new features to manage and organize the classrooms and to monitor improvements and results made by individuals along the learning process. Besides, it gives the teacher tools to create new exercises and homework activities to update and enrich the online database in a very intuitive way.

A new prototype has been developed using HTML5 and CSS3 (the original version was implemented as an eBook using Adobe Digital Publishing Suite and .folio format to produce an enhanced pdf) for a mobile open and cross-platform e cross-device result. Then it has been tested with subjects belonging to three different "personas" according to Cooper's methodology. The first group, the "traditionals", was composed by teachers older than 50 years; the second one, "innovators" was made by teachers (30-50); and "digital animator" a new school professional figure aimed to introduce students and colleges to digital technologies.

Users involved in the experiment were asked to make some basics tasks such as: create a class or set up and publish a new exercise using the features implemented in the Res Logica Magister version, using the thinking aloud protocol.

Time of execution and main and minor errors have been traced, compared and ranked to understand the principal usability and experience problems and to fix them in an iterative redesign phase.

Then the subject involved in the research, have been interviewed to understand, according to a qualitative research approach, if they would be interested in adopting the digital app or, in case of adverse answers, why they do not consider this digital tool as pedagogy support.

The paper presents and discuss the findings and compare them with the previous experimental highlights emerged in 2015 from the students' evaluation. It finally proposes some best practices and critical aspects of bringing ICT in the learning process.
\end{abstract}

Keywords: Digital technology in education, gamification approach to design, digital tool to teach grammar.

\section{REFERENCES}

1. Adobe Education Creativity Study, "GEN Z in the Classroom: Creating the Future", 2017. Retrieved from URL: http://www.adobeeducate.com/genz/

2. P. Ferri, Una nuova modalità didattica. La Scuola 2.0. Verso una didattica aumentata dalle tecnologie, Milano: Spaggiari, 2013 
3. R. Junco, \& J. Mastrodicasa, Connecting to the Net.Generation: What higher education professionals need to know about today's students, NASPA, 2001

4. L. Bollini, "Comunicare la didattica", in Piccoli Frammenti di città per abitare (M. Borsotti, ed.), pp. 231-242, Milano: CLUP, 2004

5. M. Russ, "Building a Learning Society", Wired, no. 5.10, January 1997. Retrieved from URL: https://www.wired.com/1997/10/learning/

6. R. Maragliano, Manuale di didattica multimediale, Bari: Laterza, 1994

7. L. Bollini, "The third way: hybrid scenarios in the multimodal publishing", Artlab, no. 38, pp. 44-47, Milano: Integrata Editrice, 2011

8. L. Bollini, "From paper to bytes. The transition to digital books in educational publishing: the Italian Experience", in Proceedings of ICERI 2013 Conference (L.G. Chova, A. L. Martinez, I.C. Torres eds.), pp. 757-761, Seville: IATED, 2013

9. D. Ausubel, Educational Psychology: a Cognitive View, New York: Holt, Rinehart, and Winston, 1968

10. V.P. Takač, Vocabulary learning strategies and foreign language acquisition, Clevedon, Buffalo, Toronto: Multilingual Matters LTD., 2008

11. J. Novak, "Meaningful Learning: The Essential Factor for Conceptual Change in Limited or Inappropriate Propositional Hierarchies Leading to Empowerment of Learners", Sci Ed, no. 86, pp. 548-571, 2002

12. L. Bollini, "Learning by doing: a user centered approach to signage design. Milano Bicocca a case study" in Proceedings Edulearn 2010 conference (L. G. Chova, D. M. Belenguer \& I. C. Torres eds.), pp. 3090-3097, Barcelona: IATED, 2010

13. L. Bollini, "Teaching vs. Coaching in visual design programme. A collaborative approach based on self-learning \& user-generated content", in Proceedings Edulearn 2011, pp. 3955-3961, Barcelona: IATED, 2011

14. I. Young, Mental Models Aligning Design Strategy with Human Behavior, New York: Rosenfeld Media, 2008

15. L. Bollini \& G. Palma, "Cognitive maps: new paradigms in information architecture and interface design for the web: the Opsis Identifier Descriptive Model for web information architecture based on cognitive maps: designing-X a case study" in Concept maps: Theory, methodology, technology, Vol. 2 (A. J. Canas, J. D. Novak \& F. M. Gonzalez eds.), pp. 95-98, Navarra: Nova Text, 2004

16. D. Petters, Interface Design for Learning. Design strategies for Learning experiences, Berkley: New Riders, 2014

17. L. Bollini, "Multimedialità vs. Multimodalità", I/ Verri, no. 16, pp. 144-148, 2001.

18. L. Bollini, Registica multimodale: Il design dei new media. Milano: CLUP, 2004.

19. A. Walter, Designing for emotion, New York: A Book Apart, 2011

20. D. Gray, S. Brown \& J. Macanufo, Gamestorming. A playboook for innovators, rulebreakers and changemakers, Sabastopol CA: O'Reilly, 2010

21. G. Zichermann, \& C. Cunningham, Gamification by Design. Implementing Game Mechanics in Web and Mobile Apps. O'Relly: Sabastopol CA, 2011.

22. J. Ferrara, Playful Design. Creating game experience in everyday interfaces, New York: Rosenfeld Media,, 2012

23. S. Papert, "Does it easy do it? Children, games, and learning", Game developer, June 1998. Retrieved from URL: http://www.papert.org/articles/Doeseasydoit.html

24. L. Bollini, "A gamification approach to a digital learning digital tool design: "Res Logica" a case study", in ICERI Proceedings 2014 (L.G. Chova, A. L. Martinez, I.C. Torres eds.), p. 2032, Seville: IATED, 2014

25. L. Bollini, "Learning by playing. A Gamification Approach To A Language-Learning Digital Tool", in ICERI 2015 Proceedings, pp. 5271-5278, Lisbona: IATED, 2015

26. J. Nielsen \& R. Budiu, Mobile Usability, Berkley: New Riders, 2012 
27. L. Bollini, R. De Palma, R. Nota, \& R. Pietra, "User experience \& Usability for mobile geo-referenced apps. A case study applied to cultural heritage field" in Computational science computational science and its applications - ICCSA 2014 (B. Murgante et al. eds.), Part II, LNCS 8580, pp. 652-662, Berlin Heidelberg: Springer-Verlag, 2014

28. L. Bollini, R. De Palma \& R. Nota, "Walking into the past: Design Mobile App for the Geo-referred and the Multimodal User Experience in the Context of Cultural Heritage." in Computational science computational science and its applications - ICCSA 2013 (B. Murgante, O. Gervasi, S. Misra, N. Nedjah, A. M. A. C. Rocha, D. Taniar \& B. O. Apduhan eds.), Vol. 3, pp. 481-492, Berlin Heidelberg: Springer-Verlag, 2013

29. https://labuonascuola.gov.it/

30. http://www.miur.gov.it/

31. L. Bollini, "From Skeuomorphism to Material Design and back. The language of colours in the 2nd generation of mobile interface design", in Colour and colorimetry. Multidisciplinary contributions. Vol. XII B (D. Gadia ed.), pp. 309-320, Torino: Gruppo del colore, 2016

32. L. Bollini, Large, small, medium. Progettare la comunicazione nell'ecosistema digitale. Rimini: Maggioli Editore, 2016.

33. M. Patti, Res Logica-Magister: dall'aula 2.0 a un'app per l'insegnamento dell'analisi logica, Master Degree Thesis in Teory and Technologies of Communications, University of Milano-Bicocca, 2016

34. R. Van Eck, "Digital game-based learning. It's not just the Digital Natives who are restless", EDUCASE Review, pp. 16-30, March/April 2006 